\title{
The effects of cowpea (Vigna unguiculata) feeding on basal, exogenous cholecystokinin (CCK33) and secretin stimulated pancreatic secretions of the anaesthetized rat
}

\author{
K.H. Erlwanger ${ }^{1 \#}$, E. Umapathy ${ }^{2}$, C. Musara ${ }^{1}$, E. Kandiwa ${ }^{1}$, \\ D. Kruszewska ${ }^{3}$, I. Mattsson ${ }^{4}$ and S.G. Pierzynowski ${ }^{5}$ \\ 'University of Zimbabwe, Faculty of Veterinary Science \\ Box MP 167, Mt Pleasant Harare, Zimbabwe \\ ${ }^{2}$ Department of Physiology, Faculty of Health Sciences, University of Transkei \\ P. Bag X01, Umtata, 5117 Eastern Cape Province, South Africa \\ ${ }^{3}$ Department of Medical Microbiology, Dermatology Infection \\ Lund University, Sölvegaten 23, S-223 62 Lund, Sweden \\ Institute of Ecology, Polish Academy of Sciences \\ Dziekanów Leśny, 05-092 Lomianki, Poland \\ Department of Pharmaceutical Microbiology, Medical University of Warsaw \\ 02-007 Warszawa, Oczki 3, Poland \\ ${ }^{4}$ Department of Animal Physiology, Lund University \\ Helgonawägen $3 b$, SE-223 62 Lund, Sweden \\ 5 Department of Animal Physiology, Lund University \\ Helgonawägen 3b, SE-223 62 Lund, Sweden \\ $R \& D$, Gramineer Int. AB, Ideon beta \\ SE-223 70 Lund, Sweden
}

(Received 11 October 2000; revised version 30 July 2001; accepted 7 August 2001)

\section{ABSTRACT}

To study the effects of chronic feeding of cowpea (Vigna unguiculata) on the exocrine pancreatic secretions of the rat, 32 four-week old rats were randomly assigned to four dietary groups: I. ad libitum standard rat feed (controls), II. raw cowpea ad libitum, III. cooked (boiled cowpea) ad libitum, and IV. restricted access to standard rat feed. The pancreatic duct was catheterized for total collection of pancreatic juice. After 12 weeks of dietary treatments the rats kept on cowpea

\footnotetext{
${ }^{*}$ Corresponding author
} 
diet and restrictively fed rats exhibited reduced growth and feed consumption compared to the controls. Diet had no significant effect on the volume of pancreatic juice and total protein output under basal conditions. Trypsin activity outflow in basal and stimulated conditions showed a tendency to be higher in rats fed a restricted diet and cooked cowpea diet as compared to the rats fed a standard dict and raw cowpea diet. Intra-venous CCK33 and secretin significantly increased the volume and pancreatic juice protein output in all the groups. However, potency of the stimulation for volume and pancreatic protein outputs were higher in rats fed standard diet compared to the other groups. Dietary cowpea enhanced basal as well as stimulated pancreatic secretion (volume, protein and trypsin oulputs) in a manner similar to that observed in the rats fed restricted dict.

KEY WORDS: rat, exocrine pancreas, secretion, CCK33, secretin, cowpea

\section{INTRODUCTION}

Cowpeas (Vigna unguiculata) like most other legumes have been shown to contain various antinutritional factors such as trypsin inhibitors, lectins and tannins (Gatehouse and Boulter, 1983; Mnembuka and Eggum, 1995) that are known to have deleterious effects on the growth performance, body composition and gastrointestinal systems (Grant et al., 1995; Makinde et al., 1996). However, the effects of most of the antinutritional factors can be minimized and even neutralized by various processing methods such as moist or dry heat treatment and fermentation (D'Mello, 1995). Given the shortage of protein sources in the arid regions, cowpea, which is a drought resistant crop, can go a long way toward meeting the demands for plant protein in the arid regions and also the search for novel legumes (Makinde et al., 1996).

Some of the deleterious effects of cowpea seen in other studies have been attributed to effects on the pancreas either directly or indirectly (Umapathy et al., 1999). The enzyme secretion of the pancreas is highly dependant on the diet composition (Pierzynowski et al., 1990), fecding regimen (Botermans et al., 1999), age (Pierzynowski et al., 1999) and even circadian rhythm (Thaela et al., 1995). On the other hand it has been postulated that growth of the animals and their dietary performance is closely correlated with pancreatic enzyme digestive efficiency (Botermans and Pierzynowski, 1999). Thus, as cowpea is recognized as a potential source of protein for animal nutrition in arid regions, there is need to study some of the chronic effects of cowpea on the pancreatic secretions as this is the site of origin of most of the important digestive enzymes, and the secretions of the pancreas are required for digestion.

The aims of this study were to investigate the effect of chronic feeding of cowpeas on the basal and stimulated pancreatic secretions of the pancreas in anaesthetised rats. 


\section{MATERIAL AND METHODS}

Thirty two 4-week old rats were randomly assigned to one of four groups fed on different diets: group one were fed ad libitum standard rat feed (in \%: yellow maize, 20; starch grits, 20; meat-and-bone meal, 3.2; cotton seed cake, 10; soyabean meal, 20; limestone flour, 1; salt, 0.5 ; wheat feed, 25.5; mineral/vitamin premix, 0.3) as controls, group two were fed on raw cowpea ad libitum, group three were fed cooked (boiled cowpea) ad libitum, and group four were fed on standard rat feed but with restricted access $(60 \%$ of daily ration fed to group one). All groups had free access to water at all times. The rats were adapted to a $12 \mathrm{~h}$ light cycle. After 12 weeks, the rats were starved overnight in preparation for surgery the next morning.

\section{Surgery}

The rats were anaesthetized subcutaneously with a mixture of ketamine (Ketalar, Parke-Davies, Barcelona Spain, $0.2 \mathrm{ml} / 100 \mathrm{~g}$ body weight) and azaperone (Stresnil, Janssen, Beerse, Belgium, $0.05 \mathrm{ml} / 100 \mathrm{~g}$ body weight). A silicon tubing (Silastic, i.d. $0.51 \mathrm{~mm}$, o.d. $0.94 \mathrm{~mm}$, Dow Corning, Midland, MI, USA) was surgically placed into either the left or right jugular vein. The jugular vein was reached through a ventral incision in the throat region. The catheterization was made for intravenous infusions.

A ventral midline abdominal incision was made into the abdominal cavity. The bile duct was located and ligated close to the liver to ensure pure pancreatic juice inflow in the common pancreatic-biliary duct. The common pancreatic-biliary duct was then catheterized with silicon tubing (Silastic, i.d. $0.30 \mathrm{~mm}, 0$. d. $0.63 \mathrm{~mm}$ ) near its entry into the duodenum for total collection of pure pancreatic juice.

After the surgery the rats were allowed $30 \mathrm{~min}$ to stabilise before the commencement of the experimental procedure. The rats were maintained on a heated table during the surgery and experiments and kept at a body temperature of $38^{\circ} \mathrm{C}$.

\section{Experimental protocol}

Four thirty minute pancreatic juice collections were made for each rat:

I. basal secretion

II. i.v. infusion of $0.35 \%$ BSA (Bovine Serum Albumin, Sigma, St. Louis, MO, USA) at the rate of $8 \mathrm{ml} / \mathrm{h} / \mathrm{rat}$

III. i.v. infusion of CCK33 (50 pmol/h/rat, CCK 33; Ferring AB, Malmö, Sweden) together with secretin (50 pmol/h/rat, Ferring AB, Malmö, Sweden) at the rate of $8 \mathrm{ml} / \mathrm{h} / \mathrm{rat}$. Both hormones were mixed in $0.35 \% \mathrm{BSA}$ as a carrier

IV i.v. infusion with CCK33 (250 pmol/h/rat) together with secretin $(250 \mathrm{pmol} /$ $\mathrm{h} / \mathrm{rat}$ ) also made up in $0.35 \% \mathrm{BSA}$. 
The infusions were made with an infusion pump (Harvard infusion/withdrawal model 2270, Harvard, UK). Each half hour collection was made into an Eppendorf tube and after collection the volumes were measured by visual comparison to volume standards. The samples were then stored at $-20^{\circ} \mathrm{C}$ for further analysis.

\section{Analysis}

The pancreatic juice was analysed for total protein using the Lowry method (Lowry et al., 1951) and modified to be performed on 96 well micro plates with bovine serum albumin (A-7638, Sigma) as a standard (Pierzynowski et al., 1990). Trypsin activity was measured using Na-benzoyl-DL-arginine-p-nitroanilide (Sigma) as a substrate on 96 well micro plates (Pierzynowski et al., 1990). The chemical composition of the diets was determined according to AOAC (1990). Trypsin inhibitor content was determined by the method described by Smith et al. (1980) except that the enzyme was added later as suggested by Liu and Markakis (1989).

Statistical analysis was performed by analysis of variance (ANOVA) with Turkey correction using the Instat 2 computer program.

\section{RESULTS}

The chemical composition and trypsin inhibitor content of the diets is shown in Table 1. The trypsin inhibitor content of the raw cowpea was four times higher than the cooked cowpea and thirty times higher than the control diet (Table 1). On commencement of the study when the rats were allocated to the four groups, the mean weight of the rats in the groups was $31 \pm 2.5 \mathrm{~g}$ for the control group, $30 \pm 3.2 \mathrm{~g}$ for the raw cowpea group, $31 \pm 2.6 \mathrm{~g}$ for the cooked cowpea group and $32 \pm 2.1 \mathrm{~g}$ for the restricted feed group. After twelve weeks the rats were $202 \pm 9 \mathrm{~g}, 110 \pm 12 \mathrm{~g}$, $128 \pm 15 \mathrm{~g}$ and $150 \pm 7 \mathrm{~g}$ for the four groups, respectively. Feed intake in the restricted feed group was $60 \%$, in cooked cowpea group $90 \%$ and in raw cowpea

TABLE 1

Chemical composition and trypsin inhibitor content of the standard diet and the cowpeas, as fed basis

\begin{tabular}{lccc}
\hline & Standard diet & Raw cowpea & Cooked cowpea \\
\hline Crude protein, \% & 22.0 & 26.7 & 25.7 \\
Fat, \% & 2.4 & 1.2 & 1.5 \\
Ash, \% & 7.2 & 3.6 & 3.5 \\
Gross energy, MJ/Kg & 20.0 & 18.9 & 18.8 \\
Trypsin inhibitor' & 0.2 & 6.1 & 1.6 \\
\hline
\end{tabular}

' as mg trypsin inhibited/g 
group $80 \%$ of those in control group fed standard diet. The different diets caused no significant difference in the volume of pancreatic juice and total protein content secreted by the rats under basal conditions and when BSA was infused i.v. as a carrier control to hormone infusion (Tables 2 and 3 ). Trypsin activity in basal secretions showed a tendency to be higher in the groups fed the restricted and cooked cowpea diets (Table 4).

Intravenous $\mathrm{CCK}+$ secretin significantly increased the volume and protein in all the groups in a dose dependent manner, however, the stimulation of the pancreatic juice volume outflow tended to be lower and was significantly lower in the control group as compared to the group fed cowpea diet and restricted diet, respectively. Trypsin activity outflow did not increase after exogenous CCK $33+$ secretin treatment in any of the groups. However, higher trypsin outflow was observed in rats fed cowpea diets and restricted the diet as compared to the control rats.

TABLE 2

Pancreatic juice outflow $\mathrm{ml} / \mathrm{h} / \mathrm{kg}$ in basal and stimulated conditions in anaesthetised rats fed different $\operatorname{dicts}(n=8$, mean \pm SD)

\begin{tabular}{|c|c|c|c|c|}
\hline Treatments & $\begin{array}{l}\text { Standard diet } \\
\text { ad libitum }\end{array}$ & $\begin{array}{l}\text { Raw } \\
\text { cowpea }\end{array}$ & $\begin{array}{l}\text { Cooked } \\
\text { cowpea }\end{array}$ & $\begin{array}{l}\text { Standard diet } \\
\text { restricted feed }\end{array}$ \\
\hline Basal & $0.44 \pm 0.17^{\mu}$ & $0.46 \pm 0.31^{\mathrm{a}}$ & $0.38 \pm 0.25^{a}$ & $0.57 \pm 0.29^{3}$ \\
\hline Basal + BSA' & $0.46 \pm 0.20^{\prime \prime}$ & $0.5 \mathrm{l} \pm 0.37^{\mathrm{a}}$ & $0.41 \pm 0.19^{\mathrm{a}}$ & $0.61 \pm 0.63^{\mathrm{ab}}$ \\
\hline $\mathrm{CCK}^{2}+\mathrm{SEC}^{3}$ & $1.53 \pm 0.99^{\mathrm{ab}}$ & $1.91 \pm 0.87^{\mathrm{ab}}$ & $2.00 \pm 0.73^{\text {sh }}$ & $2.30 \pm 0.66^{\mathrm{bc}}$ \\
\hline$\left(\mathrm{CCK}+\mathrm{SEC}^{*}\right) \times 5$ & $2.37 \pm 1.27^{\mathrm{b}}$ & $2.80 \pm 0.80^{\mathrm{bc}}$ & $2.60 \pm 0.94^{\mathrm{bc}}$ & $3.35 \pm 0.60^{c}$ \\
\hline
\end{tabular}

1 Bovine Serum Albumin

${ }^{2} \mathrm{CCK}+$ cholecystokinin

${ }^{3} \mathrm{SEC}-$ secretin

data with different superscripts in the columns and rows are significantly different at $\mathrm{P}<0.05$

TABLE 3

Pancreatic juice protein outputs $\mathrm{mg} / \mathrm{h} / \mathrm{kg}$ in basal and stimulated conditions in anaesthetised rats fed different diets $(n=8$, means \pm SD $)$

\begin{tabular}{lcccc}
\hline Treatments & $\begin{array}{c}\text { Standard diet } \\
\text { ad libitum }\end{array}$ & $\begin{array}{c}\text { Raw } \\
\text { cowpea }\end{array}$ & $\begin{array}{c}\text { Cooked } \\
\text { cowpea }\end{array}$ & $\begin{array}{c}\text { Standard diet } \\
\text { restricted feed }\end{array}$ \\
\hline Basal & $54 \pm 31^{\mathrm{a}}$ & $40 \pm 37^{\mathrm{a}}$ & $47 \pm 17^{\mathrm{a}}$ & $68 \pm 46^{\mathrm{a}}$ \\
Basal + BSA & $60 \pm 4^{\mathrm{a}}$ & $63 \pm 36^{\mathrm{a}}$ & $66 \pm 20^{\mathrm{a}}$ & $82 \pm 50^{\mathrm{a}}$ \\
CCK+SEC & $121 \pm 77^{\mathrm{ab}}$ & $156 \pm 75^{\mathrm{ab}}$ & $172 \pm 71^{\mathrm{ab}}$ & $153 \pm 52^{\mathrm{ab}}$ \\
$(\mathrm{CCK}+$ SEC $) \times 5$ & $160 \pm 68^{\mathrm{b}}$ & $321 \pm 211^{\mathrm{b}}$ & $190 \pm 103^{\mathrm{b}}$ & $234 \pm 190^{\mathrm{b}}$ \\
\hline
\end{tabular}

BSA, CCK and SEC as in Table 2

data with different superscripts in the columns and rows are significantly different at $\mathrm{P}<0.05$ 
TABLE 4

Pancreatic juice trypsin outflow $\mathrm{U} / \mathrm{h} / \mathrm{kg}$ in basal and stimulated conditions in anaesthetised rats fed different diets $(n=8$, mean $\pm S D)$

\begin{tabular}{lcccc}
\hline Treatments & $\begin{array}{c}\text { Standard dict } \\
\text { ad libitum }\end{array}$ & $\begin{array}{c}\text { Raw } \\
\text { cowpea }\end{array}$ & $\begin{array}{c}\text { Cooked } \\
\text { cowpea }\end{array}$ & $\begin{array}{c}\text { Standard diet } \\
\text { restricted feed }\end{array}$ \\
\hline Basal & $290 \pm 19^{\mathrm{ab}}$ & $240 \pm 61^{\mathrm{ab}}$ & $355 \pm 12^{\mathrm{b}}$ & $405 \pm 14^{\mathrm{b}}$ \\
Basal + BSA & $275 \pm 57^{\mathrm{ab}}$ & $259 \pm 35^{\mathrm{ab}}$ & $356 \pm 99^{\mathrm{b}}$ & $391 \pm 95^{\mathrm{b}}$ \\
CCK+SEC & $191 \pm 60^{\mathrm{a}}$ & $249 \pm 64^{\mathrm{ab}}$ & $313 \pm 11^{\mathrm{b}}$ & $415 \pm 80^{\mathrm{b}}$ \\
$(\mathrm{CCK}+$ SEC $) \times 5$ & $184 \pm 51^{\mathrm{a}}$ & $241 \pm 58^{\mathrm{b}}$ & $246 \pm 98^{\mathrm{bb}}$ & $389 \pm 83^{\mathrm{b}}$ \\
\hline
\end{tabular}

BSA, CCK and SEC as in Table 2

data with different superscripts in the columns and rows are significantly different at $\mathrm{P}<0.05$

\section{DISCUSSION}

A comparison of the rats growth and enzyme secretion exhibited an interesting pattern: the best growth performance with minimal enzyme secretion was observed in the rats fed conventional diet ad libitum. Restricted access to the feed and dietary cowpea made the pancreas more sensitive to hormonal stimulation and caused higher basal pancreatic secretion. A $40 \%$ reduction in conventional feed only inhibited the growth by $25 \%$. Considering that at the same time pancreatic secretion was enhanced, one can speculate that high pancreatic secretion when animals are exposed to the lack of food increases utilization of the food. This however, needs to be studied more profoundly. On the other hand, feeding the rat cowpea slightly lowered their feed consumption and significantly increased their pancreatic secretion. This however, was not correlated with improved feed utilization. On the contrary, feed utilization in both cowpea groups was significantly low. Thus, we can speculate that antinutrients in cowpea inhibited pancreatic enzyme digestion capacity in the intestinal lumen and in this way via feedback mechanisms stimulated higher pancreatic secretion (Fushiki et al., 1999). It is not to be excluded that cowpea - other than trypsin inhibitor - antinutritional factors could also have diminished the utilization of the food e.g., via diminished absorption of the nutrients since trypsin inhibitor level in one of experimental feed was effectively reduced via heat treatment and this only slightly improved growth of the animals in that group.

The rats that were fed the cowpea (raw and cooked) did not receive any other supplements thus the effects on the exocrine pancreatic secretions can be attributed to the cowpea. Diet had no effect on volume and total protein of the basal secretion of pancreatic juice. In rats and chickens, it has been shown that feeding raw soyabean or soyabean trypsin inhibitors resulted in hypersecretion of pancre- 
atic enzymes and hypertrophy of the pancreas (Corring et al., 1986; Sauer and Mosenthin, 1999). Our results are in agreement with those since trypsin activity outflow was higher in rats fed raw and cooked cowpea. Sauer and Mosenthin (1999), in a review on antinutritional factors and the exocrine pancreas in pigs, have shown that there have been contradicting results on the effects of raw and processed soyabean on the exocrine pancreas. Żebrowska et al. (1983) showed an increase in volume of pancreatic secretion and protein but no effect on the activities of trypsin, chymotrypsin, carboxypeptidases A and B and amylase whilst Schumann et al. (1983) reported an increase in volume of secretion and doubling of protein secretion. Pancreatic enzymes were also reported to have been increased by feeding soyabean trypsin inhibitors. In a study to determine the effect of trypsin inhibitors in peas on the exocrine pancreas secretion of pigs, Gabert et al. (1996) showed that there was no effect on volume, protein and enzyme activitics. Dictary inclusion of faba beans (which are high in tannins) in pigs also had no effect on the pancreatic secretions (Gabert et al., 1996). In a study on the effects of cowpea feeding on exocrine pancreatic secretions in pigs, dietary cowpea significantly reduced volume of secretions and total protein but trypsin activity was increased (Umapathy et al., 1999). Even pancreatic homogenates from pigs fed cowpea did not show any differences in protein content and trypsin activity (Erlwanger et al., 1999). It would thus appear that the differences that have been noted in studies may have been based on species differences and differences in the methods of collection of pancreatic juice and whether total or specific activities of enzymes are measured. Thus the finding that there was no difference in the protein and volume of pancreatic juice between our dietary groups could be in line with findings from pigs. The major differences in our study are seen in the trypsin activity, which, in the basal state was lowest in the raw cowpea fed rats, and, highest in the restricted fed rats. This could indicate that the raw cowpea had a suppressive effect on the trypsin activity outflow and the suppressive "factor" was heat-labile. Although we did not measure the weights of the pancreas from the rats for comparison, chronic feeding of cowpea to rats has been shown to induce an extensive increase in the relative and absolute weights of the pancreas and also caused an increase in the incidence of macroscopic pancreatic nodules (Grant et al., 1995). Infusion of the secretagogues resulted in an increase in volume and protein content of the pancreatic juice as expected. The lack of the effect on trypsin activity is puzzling and needs to be explored in further experiments.

It can be concluded that raw cowpea did not affect the basal and stimulated volume and protein output of pancreatic juice in the rat and slightly stimulated basal trypsin activity outflow. However, considering the body weight gain of the animals kept on the diets containing raw and cooked cowpea we postulate that cowpea antinutritional factors reduce utilization of the food probably via altered digestion of the feed components. Proportionally the best performance was seen in 
the group kept on the restricted diet and as it was characterized by the highest pancreatic function led us to speculate that higher pancreatic secretion can improve utilization of the diet.

\section{ACKNOWLEDGEMENTS}

The authors would like to thank the European Union-University of ZimbabweFaculty of Veterinary Science Link program for funding this study. Grants from Director A. Påhlsson's Foundation and the Swedish Council for Forestry and Agricultural Research are gratefully acknowledged. The technical input of Mr F. Chimudzi, and Mr G. Tandaupenyu (University of Zimbabwe) is also acknowledged.

\section{REFERENCES}

Botermans J.A.M., Pierzynowski S.G., 1999. Relations between body live weight, feed intake, daily weight gain and pancreatic exocrine secretion in growing pigs. J. Anim. Sci. 77, 450- 456

Botermans J.A.M., Svendsen J., Svendsen L.S., Pierzynowski S.G., 1999. The exocrine pancreas in pig growth and performance. In: S.G. Pierzynowksi, R. Zabielski (Editors). Biology of the Pancreas in Growing Animals. Elsevier Science B.V., pp. 395-408

Corring T., Gueugneu A.M., Chayvialle J.A., 1986. Short-term (8-day) effects of a raw soybean diet on exocrine pancreatic secretion and plasma gastrointestinal hormone levels in the pig. Reprod. Nutr. Develop. 26, 503-514

Cuber J.-C., Corring T., Levenez F., Bernard C., Chayvialle J.-A., 1989. Effects of cholecystokinin octapeptide on pancreatic secretion in the pig. Can. J. Physiol. Pharmacol. 67, 1391-1397

D'Mello J.P.F., 1995. Antinutritional substances in legume seeds. In: J.P.F. D’Mello, C. Devendra (Editors). Tropical Legumes in Animal Nutrition. CAB Intemational, pp.135-172

Erlwanger K.H., Unmack M.A., Grondahl M.L., Picrzynowski S.G., Aalbaek B., Dantzer V., Skadhauge E., 1999. Effects of dietary substitution with raw and heat treated cowpea (Vigna unguiculata) on intestinal transport and pancreatic enzymes in the pig. J. Vet. Med. A 46, $581-592$

Fushiki T., Tsuzuki S., Pierzynowski S.G., 1999. Feedback regulation of pancreatic secretion. In: S.G. Pierzynowksi, R. Zabielski (Editors). Biology of the Pancreas in Growing Animals. Elsevier Science B.V., pp. 249-259

Gabert V.M., Sauer W.C., Li S., Fan M.Z., Rademacher J., 1996. Exocrine pancreatic secretion in young pigs fed dicts containing faba beans (Vicia faba) and peas (Pisum sativum): nitrogen, protein and enzyme secretions. J. Sci. Food. Agr. 70, 247-245

Gatehouse A.M.R., Boulter D., 1983. Assessment of antimetabolic effects of trypsin inhibitors from cowpea (Vigna unguiculata) and other legumes on development of the bruchid beetle Callosobruchus masculatus. J. Sci. Food Agr. 34, 345- 350

Grant G., Dorward P.M., Buchan W.C., Armour J.C., Pusztai A., 1995. Consumption of diets containing raw soya beans (Glycine max), kidney beans (Phaseolus vulgaris), cowpeas (Vigna 
unguiculata) or lupin seeds (Lupinus angustifolius) by rats up to 700 days: effects of body composition and organ weights. Brit. J. Nutr. 73, 17-29

Liu K., Markakis P., 1989. Trypsin inhibitorassay as related to limited hydrolysis of inhibitors. Anal. Biochem. 178, 159-165

Lowry O.H., Rosebrough N., Farr A.S., Randall R.J., 195I. Protein measurement with the Folin phenol reagent. J. Biol. Chem. 193, 265-275

Makinde M.O., Umapathy E., Akingbemi B.T., Mandisodza K.T., Skadhauge E., 1996. Effects of dietary soybean and cowpea on gut morphology and faecal composition in creep fed and non creep fed pigs. J. Vet. Med. A 43, 75-85

Mnembuka B.V., Eggum B.O., 1995. Comparative nutritive value of the winged bean, (Phosphocarpus tetragonlobus (L) DC) and other legumes grown in Tanzania. Plant Food Hum. Nutr. 47, 333339

Nell F.J., Scibrits F.K., Hayes J.P., 1992. Studies on the nutritive value of cowpeas (Vigna unguiculata). S. Afr. J. Anim. Sci. 22, $157-160$

Pierzynowski S.G., Rehfeld J.F., Olsen O., Karlsson S., Ahrén B., Podgurniak M., Karlsson B.W., Weström B.R., 1999. Mode of exocrine pancreatic function and regulation in pigs at weaning. In: S.G. Pierzynowksi, R. Zabielski (Editors). Biology of the Pancreas in Growing Animals. Elsevier Science B.V., pp. 231-248

Pierzynowski S.G., Weström B.R., Svendsen J., Karlsson B.W., 1990. Development of exocrine pancreas function in chronically cannulated pigs during $1-13$ weeks of postnatal life. J. Pedriat. Gastroenterol. Nutr. 10, 206-212

SAS, 1996. SAS Users Guide: Statistics, SAS Institute., Inc., Cary (USA)

Sauer W. C., Mosenthin R., 1999. Antinutritional factors and exocrine pancreatic secretion in pigs. In: S.G. Picrzynowksi, R. Zabiclski (Editors). Biology of the Pancreas in Growing Animals. Elsevier Science B.V., pp. 371-380

Smith C., Van Megan W., Twaalfhoven L., Hitchcock C., 1980. The determination of trypsin inhibitor levels in foodstuffs. J. Sci. Food Agr. 31, 341-350

Thaela M.-J., Pierzynowski S. G., Jensen S., Jacobsen K., Westrom B. R., Karlsson B. W., 1995. The pattern of the circadian rhythm of pancreatic secretion in fed pigs. J. Anim. Sci. 73, 3402-3408

Umapathy E., Erlwanger K.H., Makkar H.P.S., Becker K., Pierzynowski S.G., 1999. Effects of cowpea (Vigna unguiculata) feeding on the pancreatic exocrine secretion of pigs. J. Anim. Physiol. Anim. Nutr. 82, 57-65

Zabielski R., Pierzynowski S.G., Podgurniak P., Sharma P., Barej W., 1992. Effects of secretin and cholecstokinin octapeptide (CCK8) on exocrine pancreas during cold vagal blockade in calves. J. Anim. Physiol. Anim. Nutr. 67, 173-188

Żebrowska T., Low A., Żebrowska H., 1983. Studies on gastric digestion of protein, and carbohydrate, gastric secretion and exocrine pancreatic secretion in the growing pig. Brit. J. Nutr. 49, 401-410 


\section{STRESZCZENIE}

\section{Wpływ skarmiania krowiego grochu (Vigna unguiculate) na podstawową oraz stymulowaną cholecystokininą (CCK33) i sekretyną zewnętrzną sekrecję trzustki u szczurów w narkozie}

Badania nad wplywem długotrwałego skarmiania krowiego grochu na zewnętrzne wydzielanie trzustki u szczurów, przeprowadzono na 32 cztcrotygodniowych szczurach, podzielonych losowo do 4 grup żywieniowych: I. zwierzęta żywione do woli standardową paszą (kontrolna), JI. surowy krowi groch podawany do woli, III. gotowany krowi groch podawany do woli, oraz IV, ograniczony dostçp do paszy standardowej. Do przewodu trzustkowego założony był kateter umożliwiający całkowitą kolekcję soku trzustkowego.

Po 12 tygodniach żywienia, szczury otrzymujące diety z krowiego grochu oraz ograniczoną ilość paszy standardowej pobierały mniej paszy i gorzej rosły niż zwierzęta grupy kontrolnej. Rodzaj diety nie miał istotnego wpływu na objętość i ogólną ilość białka wydzielanych w warunkach podstawowych. Wystapiła tendencja zwiçkszonej aktywności trypsyny w podstawowych i stymulowanych warunkach u szczurów olrzymujących ograniczoną ilość paszy oraz gotowany krowi groch w porównaniu z dwiema pozostalymi grupami. Dożylne podawanic CCK33 i sckretyny powodowały istotny wzrost objętości i białka wydzielanego w soku u szczurów wszystkich grup. Jednakże stymulowane wydzielanie soku trzustkowego (objętości) i białka było większe u szczurów otrzymujących dietę standardową w porównaniu z pozostałymi.

Skarmianie krowiego grochu zwiększa podstawową oraz stymulowaną sekrecję trzustki (objętość, wydziclanic białka i trypsyny) w podobnym stopniu jak u szczurów, którym podawano ograniczoną ilość paszy. 